\title{
Nutrient demand interacts with forage family to affect nitrogen digestion and utilization responses in dairy cows
}

\author{
J. A. Voelker Linton and M. S. Allen ${ }^{1}$ \\ Department of Animal Science, Michigan State University, East Lansing 48824
}

\begin{abstract}
The effect of preliminary feed intake on responses to diets containing alfalfa silage or orchardgrass silage was evaluated using 8 ruminally and duodenally cannulated Holstein cows in a crossover design experiment with a 14-d preliminary period and two 15-d treatment periods. Responses measured were intake, digestion, and utilization of $\mathrm{N}$. Cows were $139 \pm 83$ (mean \pm standard deviation) days in milk at the beginning of the preliminary period. During the $14-\mathrm{d}$ preliminary period, $3.5 \%$ fat-corrected milk yield ranged from 23.9 to $47.6 \mathrm{~kg} / \mathrm{d}$ (mean $=36.9 \mathrm{~kg} / \mathrm{d})$ and preliminary voluntary dry matter intake (pVDMI) ranged from 14.2 to $21.3 \mathrm{~kg} / \mathrm{d}($ mean $=18.6 \mathrm{~kg} / \mathrm{d})$. Treatments were a diet with alfalfa silage as the sole forage (AL) and a diet with orchardgrass silage as the sole forage (OG). Alfalfa silage contained $20.5 \%$ crude protein (CP; dry matter basis) and orchardgrass silage contained $20.4 \%$ $\mathrm{CP}$; AL contained $18.3 \% \mathrm{CP}$ and $5.6 \%$ estimated rumen-undegraded $\mathrm{CP}$, and $\mathrm{OG}$ contained $18.8 \% \mathrm{CP}$ and $6.3 \%$ estimated rumen-undegraded CP. Mean N intake was similar between treatments, ruminal $\mathrm{N}$ digestibility was greater for $\mathrm{AL}(30.4 \%)$ than for OG (17.7\%), and whole-tract $\mathrm{N}$ digestibility did not differ between treatments. Intake and duodenal flow of $\mathrm{N}$ depended on a treatment $\times$ pVDMI interaction; both $\mathrm{N}$ intake and duodenal flow increased more for AL than for OG as pVDMI increased. Duodenal flow of microbial $\mathrm{N}$ and the efficiency of microbial $\mathrm{N}$ production from $\mathrm{OM}$ also depended on a treatment $\times$ pVDMI interaction in a manner similar to $\mathrm{N}$ intake and duodenal flow. However, treatment $\times$ pVDMI interactions also indicate that as pVDMI increased and $\mathrm{N}$ intake increased for AL compared with OG, a decreasing proportion of the additional $\mathrm{N}$ consumed from $\mathrm{AL}$ was digested and used for increased milk protein production or body tissue gain. Therefore, when feeding less-filling diets, such as those containing large proportions of legume forage, to high-producing cows, reducing dietary $\mathrm{N}$ concentration
\end{abstract}

Received May 4, 2008

Accepted November 30, 2008.

${ }^{1}$ Corresponding author: allenm@msu.edu could increase the efficiency of $\mathrm{N}$ utilization and reduce the extent to which greater DMI leads to greater $\mathrm{N}$ excretion.

Key words: nutrient demand, grass, legume, nitrogen utilization

\section{INTRODUCTION}

Legumes typically contain higher CP and lower fiber concentrations than grasses. The fiber concentrations of forages determine optimal dietary forage concentration and therefore also determine the dietary concentration of forage N. Thus, including a forage with lower fiber and higher $\mathrm{N}$ concentration-such as alfalfa-will result in a higher dietary concentration of forage $\mathrm{N}$. Therefore, using alfalfa alone to meet requirements for forage fiber often results in excess dietary $\mathrm{N}$ in a form that is degraded rapidly to $\mathrm{NH}_{3}$ in the rumen. Grasses can reduce the ratio of $\mathrm{N}$ to fiber in forage (Spandl and Hesterman, 1997) and therefore can reduce fecal and urinary $\mathrm{N}$ waste excreted by cows.

Grass fiber and alfalfa fiber also have different chemical compositions, physical characteristics, and digestion characteristics that typically cause alfalfa particles to have a shorter ruminal retention time than grass particles (Waghorn et al., 1989; Wilson and Hatfield, 1997; Voelker Linton and Allen, 2008). Faster escape of particle-associated bacteria from the rumen (shorter residence time) increases efficiency of $\mathrm{N}$ and energy utilization (Oba and Allen, 2003b; Voelker and Allen, 2003) by decreasing bacterial death and breakdown in the rumen (Stouthamer and Bettenhaussen, 1973; Isaacson et al., 1975). Microbial protein flow to the duodenum is limited by the availability of readily fermented feed for growth and by the ability of bacteria to avoid predation or lysis and escape the rumen. Therefore, increasing passage rate of particles and bacteria from the rumen should cause increased microbial protein flow to the duodenum and increased efficiency of microbial protein synthesis. Although grass NDF usually is more digestible than alfalfa NDF, grass NDF is digested more slowly than alfalfa NDF, and grass particles are more resistant to breakdown than are alfalfa particles (Wilson and Hatfield, 1997). Therefore, 
the effect of slow passage rate of grass likely outweighs any benefit resulting from more digestible NDF. Thus, replacing a legume forage with a grass forage not only would decrease the ratio of $\mathrm{N}$ to fiber in the forage; it also likely would reduce passage rate and might lower microbial protein efficiency.

Although a direct comparison of a legume forage (alfalfa silage) and a grass forage (orchardgrass silage) will demonstrate the effects on $\mathrm{N}$ utilization that can be expected by partially or entirely replacing legume forage with grass forage, the passage rate of fiber from the rumen does not only depend on forage family; it also depends on nutrient demand of animals (Voelker et al., 2002). That is, animals with different demands for intake respond differently to forages with different physical filling effects, such as grasses and legumes. We developed and have used successfully an experimental model to evaluate effects of preliminary voluntary DMI (pVDMI), an index of nutrient demand, on animal responses to dietary treatments (Oba and Allen, 1999; Voelker et al., 2002; Voelker Linton and Allen, 2007). The use of pVDMI provides an indicator of nutrient demand that is independent of the treatments. This model was utilized to test our hypothesis that pVDMI and forage source (alfalfa vs. orchardgrass) interact in affecting $\mathrm{N}$ intake, digestion, and utilization.

\section{MATERIALS AND METHODS}

\section{Cows and Treatments}

Experimental procedures were approved by the All University Committee on Animal Use and Care at Michigan State University and were described in detail previously (Voelker Linton and Allen, 2008). Eight multiparous Holstein cows from the Michigan State University Dairy Cattle Teaching and Research Center were assigned randomly to treatment sequence in a crossover design experiment with a 14-d preliminary period and two 15-d experimental periods. These 8 cows were selected deliberately to provide a wide, uniform distribution of milk yield and DMI (Figure 1); $3.5 \% \mathrm{FCM}$ yield was $36.9 \pm 9.8$ (mean $\pm \mathrm{SD}$ ) $\mathrm{kg} / \mathrm{d}$ and DMI was $18.6( \pm 2.8) \mathrm{kg} / \mathrm{d}$. Cows had a mean of 139 $( \pm 83)$ DIM, mean BW of $538( \pm 17) \mathrm{kg}$, mean BCS of $2.5( \pm 0.4)$, and mean parity of $4.0( \pm 2.6)$. Cows were cannulated ruminally and duodenally before calving. Cows were housed in tie-stalls and fed once daily (1100 h) at $110 \%$ of expected intake.

Treatments were a diet with alfalfa silage as the sole forage (AL) and a diet with orchardgrass silage as the sole forage (OG). Alfalfa and orchardgrass forages were produced at the campus farm at Michigan State University and ensiled in Ag-Bags (Ag-Bag Systems Inc.,
St. Nazianz, WI). Alfalfa was harvested at early bud stage, chopped at $0.95 \mathrm{~cm}$ theoretical length of cut, and ensiled at $36 \% \mathrm{DM}$. Orchardgrass was harvested at early boot stage, chopped at $0.64 \mathrm{~cm}$ theoretical length of cut, and ensiled at 37\% DM. Cut lengths were selected to yield similar particle size distributions using the Pennsylvania State Particle Size Separator (Nasco, Fort Atkinson, WI; Lammers et al., 1996). Proportions of fresh-chopped forage retained on the top sieve (19-mm aperture) varied greatly by sample batch and averaged $20.1 \%$ for alfalfa and $28.1 \%$ for orchardgrass. Mean total mass retained on the top and middle (8$\mathrm{mm}$ aperture) sieves were similar for alfalfa (62\%) and orchardgrass (58\%). During the sample collection periods, alfalfa silage contained $43 \%$ NDF (DM basis) and orchardgrass silage contained $48 \%$ NDF (Table 1). Diets AL and OG were formulated to contain $23 \%$ forage NDF and $27 \%$ total NDF, so forage-to-concentrate ratios (DM basis) were 53:47 for $\mathrm{AL}$ and 48:52 for $\mathrm{OG}$ (Table 2). The diet fed during the preliminary period was formulated so that alfalfa silage and orchardgrass silage each contributed $50 \%$ of forage NDF (Table 2). Diets were fed once daily as TMR and also contained dry ground corn, soybean meal (48\% CP), SoyPlus (West Central Soy, Ralston, IA), a vitamin-mineral premix, and blood meal. Limestone was used in OG to compensate for lower anticipated $\mathrm{Ca}$ concentration in orchardgrass silage (Table 2). Before the experiment started, CP concentration was lower in the orchardgrass silage than in alfalfa silage, so urea and bloodmeal were used to bring both diets to $18 \%$ dietary CP. However, during the experimental periods, orchardgrass silage $\mathrm{CP}$ concentration was similar to alfalfa silage $\mathrm{CP}$ concentration, so dietary $\mathrm{CP}$ was $0.5 \%$ higher on a diet DM basis in OG than in AL.

\section{Data and Sample Collection and Analysis}

General methods for data and sample collection and analysis were reported in Voelker Linton and Allen (2008). Crude protein concentrations were determined according to Hach et al. (1987). Duodenal digesta were analyzed for purines and $\mathrm{NH}_{3}$ to estimate microbial $\mathrm{N}$ (MN) flow and nonammonia, nonmicrobial $\mathrm{N}$ flow to the duodenum. Purine concentration was used as a microbial marker, and purine-to-MN ratio was estimated by analysis of microbial pellets obtained by differential centrifugation of the rumen fluid collected in the reticulum. Rumen fluid first was centrifuged at $500 \times g$ for $15 \mathrm{~min}$. The supernatant was centrifuged at $18,000 \times g$ for $15 \mathrm{~min}$, and the pellet was washed with $0.9 \% \mathrm{NaCl}$ solution and centrifuged again at 18,000 $\times g$ for 15 min, resuspended in water, and lyophilized. Total purines were measured by spectrophotometer (Beckman 
Table 1. Chemical characterization of alfalfa silage and orchardgrass silage

\begin{tabular}{lcc}
\hline Item & $\begin{array}{c}\text { Alfalfa } \\
\text { silage }\end{array}$ & $\begin{array}{c}\text { Orchardgrass } \\
\text { silage }\end{array}$ \\
\hline DM, \% as fed & 30.6 & 35.3 \\
Nutrient, \% DM & & \\
OM & 88.7 & 89.2 \\
NDF & 42.6 & 48.0 \\
Indigestible NDF & 25.2 & 13.1 \\
Potentially digestible NDF & 17.4 & 34.9 \\
Starch & 4.0 & 2.3 \\
CP & 20.5 & 20.4 \\
30-h in vitro NDF & 29.4 & 61.1 \\
digestibility, \% & & \\
\hline
\end{tabular}

Instruments Inc., Fullerton, CA) at $260 \mathrm{~nm}$ according to Zinn and Owens (1986). Ammonia concentration was determined for centrifuged duodenal and rumen fluid samples according to Broderick and Kang (1980). Duodenal flow of microbial OM was determined as described by Oba and Allen (2003a), and true ruminally degraded OM was calculated by subtracting duodenal flow of nonmicrobial OM from OM intake. Turnover

\section{Preliminary VDMI, kg/d}

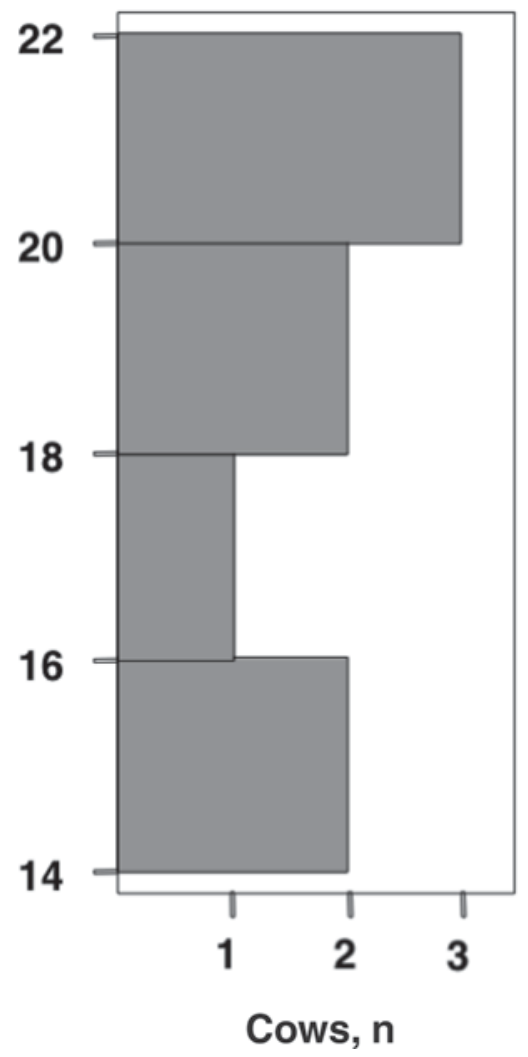

time of $\mathrm{N}$ in the rumen was calculated using the following equation: $24 \times$ ruminal pool of component/daily intake of component.

Milk samples were analyzed for true protein with infrared spectroscopy by Michigan DHIA (East Lansing). Milk true protein $\mathrm{N}$ yield was calculated as milk true protein yield/6.38 (Jenness, 1985), and efficiency of $\mathrm{N}$ utilization for true protein production was calculated as milk true protein $\mathrm{N}$ yield/ $\mathrm{N}$ intake. Milk samples from the first experimental period only were analyzed for MUN with infrared spectroscopy by Michigan DHIA; because data were available for only 1 period, a $t$-test was used to determine the difference between treatments for MUN.

Methods for all other statistical analyses were reported in Voelker Linton and Allen (2008). Preliminary voluntary DMI was calculated as the mean of DMI values on d 11 to 14 of the 14-d preliminary period. The hypothesis was tested using the following model:

$$
\begin{gathered}
\mathrm{Y}_{\mathrm{ijk}}=\mu+\mathrm{C}_{\mathrm{i}}+\mathrm{P}_{\mathrm{j}}+\mathrm{T}_{\mathrm{k}}+\mathrm{PT}_{\mathrm{jk}}+\mathrm{pVDMI}_{\mathrm{i}} \\
+\mathrm{T} \mathrm{pVDMI} \mathrm{ki}_{\mathrm{i}}+\mathrm{e}_{\mathrm{ijk}},
\end{gathered}
$$

\section{Preliminary $3.5 \%$ FCM yield, $\mathrm{kg} / \mathrm{d}$}

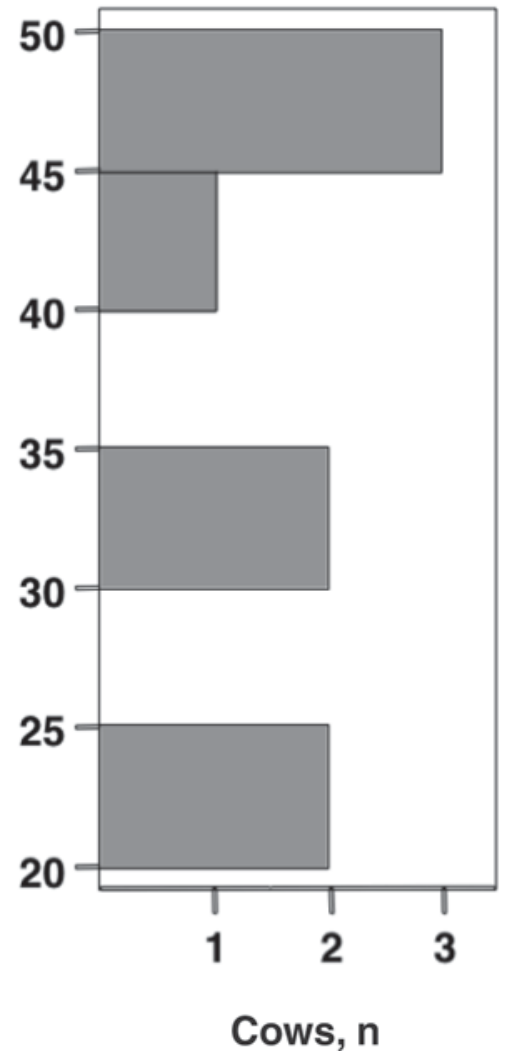

Figure 1. Distribution of DMI and 3.5\% FCM yield of 8 cows during the final $4 \mathrm{~d}$ of the 14-d preliminary period, when cows were fed a common diet. 
where $\mu=$ overall mean; $\mathrm{C}_{\mathrm{i}}=$ random effect of cow (i $=1$ to 8$) ; \mathrm{P}_{\mathrm{j}}=$ fixed effect of period $(\mathrm{j}=1$ or 2$) ; \mathrm{T}_{\mathrm{k}}$ $=$ fixed effect of treatment $(\mathrm{k}=1$ or 2$) ; \mathrm{PT}_{\mathrm{jk}}=$ period $\times$ treatment; $\mathrm{pVDMI}_{\mathrm{i}}=$ effect of $\mathrm{pVDMI} ; \mathrm{T}_{\mathrm{pVDMI}}$ $=$ treatment $\times$ pVDMI; and $\mathrm{e}_{\mathrm{ijk}}=$ residual, which was assumed to be normally distributed.

The hypothesis was tested by determining the significance of the interaction between pVDMI and treatment in the prediction equation for response Y. Significance for main effects was declared at $P \leq 0.05$, and tendencies were declared at $P \leq 0.10$. Significance for interactions was declared at $\bar{P} \leq 0.10$, and tendencies were declared at $P \leq 0.15$. Both the significance of the treatment $\times$ pVDMI interaction term and the signs of the coefficients for the interaction term (when significant) are reported and discussed. All treatment means are least squares means.

\section{RESULTS AND DISCUSSION}

\section{N Digestion: AL Versus OG}

Diet $\mathrm{CP}$ and estimated rumen-undegraded $\mathrm{CP}$ concentrations were similar for $\mathrm{OG}$ and $\mathrm{AL}$ (Table 2). Because mean DMI was similar for the 2 treatments $(P$ $=0.25)$ and dietary $\mathrm{N}$ concentrations were similar, $\mathrm{N}$ intake was not affected by treatment $(P=0.90$; Table 3). Ruminal $\mathrm{N}$ pool was greater for $\mathrm{OG}$ than for AL ( $P$ $=0.04$ ), and ruminal turnover time of $\mathrm{N}$ was longer on OG than on AL $(P=0.01$; Table 3$)$. This was probably the result of a slower passage rate of digesta from the rumen for OG (Voelker Linton and Allen, 2008) and possibly because of greater proteolysis for AL. The 2 silages contained similar concentrations of $\mathrm{N}$, but protein from alfalfa usually is degraded more rapidly and extensively in the rumen than is protein from grasses (Kwakkel et al., 1986; Kohn and Allen, 1995). Ruminal pool and turnover time of total $\mathrm{N}$ were greater for $\mathrm{OG}$ than for $\mathrm{AL}$, and ruminal $\mathrm{NH}_{3}$ concentration was much greater for AL $(29.3 \mathrm{mg} / \mathrm{dL})$ than for $\mathrm{OG}(18.0 \mathrm{mg} /$ $\mathrm{dL} ; P<0.01)$. Apparently, $\mathrm{N}$ remained in the rumen longer on $\mathrm{OG}$ than on $\mathrm{AL}$ in part because more ruminal $\mathrm{N}$ existed in the form of $\mathrm{NH}_{3}$ when cows were fed AL. Also, ruminal $\mathrm{pH}$ likely contributed to longer ruminal $\mathrm{N}$ turnover time for $\mathrm{OG}$ than for AL. Mean ruminal $\mathrm{pH}$ was lower for OG than for AL $(P<0.01$; Table 3$)$, suggesting that rate of ruminal $\mathrm{NH}_{3}$ absorption was slower for OG than for AL for 2 reasons. First, lower $\mathrm{pH}$ causes a slower rate of absorption because more $\mathrm{NH}_{3}$ is converted to ammonium, which is absorbed much more slowly than $\mathrm{NH}_{3}$ (Abdoun et al., 2006). Second, lower $\mathrm{pH}$ may inhibit rumen motility (Leek and Harding, 1975), reducing mixing in the rumen and rate of $\mathrm{NH}_{3}$ absorption. For $\mathrm{OG}$, less $\mathrm{N}$ available as $\mathrm{NH}_{3}$ and
Table 2. Ingredient and nutrient composition of preliminary diet and treatment diets: 1 diet (AL) containing alfalfa silage and another diet (OG) containing orchardgrass silage

\begin{tabular}{|c|c|c|c|}
\hline Item & Preliminary & $\mathrm{AL}$ & $\mathrm{OG}$ \\
\hline \multicolumn{4}{|l|}{ Ingredient } \\
\hline Alfalfa silage & 25.4 & 53.0 & - \\
\hline Orchardgrass silage & 21.5 & - & 47.9 \\
\hline Dry ground corn & 39.8 & 36.3 & 40.3 \\
\hline Soybean meal ( $48 \% \mathrm{CP})$ & 6.1 & 6.5 & 7.0 \\
\hline Vitamin-mineral mix ${ }^{1}$ & 4.4 & 4.2 & 4.2 \\
\hline SoyPlus $^{2}$ & 1.6 & 1.3 & 1.3 \\
\hline Bloodmeal & 0.4 & 0.3 & 0.9 \\
\hline Limestone & 0.6 & - & 0.4 \\
\hline Urea & 0.2 & - & 0.2 \\
\hline \multicolumn{4}{|l|}{ Nutrient } \\
\hline DM, $\%$ as fed & 46.4 & 43.6 & 50.6 \\
\hline $\mathrm{OM}$ & 91.4 & 91.5 & 91.5 \\
\hline $\mathrm{NDF}$ & 25.8 & 26.7 & 27.5 \\
\hline Forage NDF & 21.1 & 22.5 & 23.0 \\
\hline Indigestible NDF & 10.8 & 14.8 & 7.9 \\
\hline Potentially & 15.0 & & \\
\hline digestible NDF & & 11.9 & 19.7 \\
\hline Starch & 33.1 & 30.2 & 32.1 \\
\hline $\mathrm{CP}$ & 18.7 & 18.3 & 18.8 \\
\hline Rumen-undegraded $\mathrm{CP}^{3}$ & 6.0 & 5.6 & 6.3 \\
\hline
\end{tabular}

${ }^{1}$ Vitamin-mineral mix contained (DM basis) $11.7 \%$ dicalcium phosphate, $11.1 \%$ trace-mineral premix, $8.8 \%$ sodium bicarbonate, $2.3 \%$ magnesium oxide, $134.3 \mathrm{kIU} / \mathrm{kg}$ of vitamin A, $35.53 \mathrm{kIU} / \mathrm{kg}$ of vitamin $\mathrm{D}, 895.5 \mathrm{kIU} / \mathrm{kg}$ of vitamin $\mathrm{E}$, and $65.2 \%$ ground corn grain as a carrier.

${ }^{2}$ West Central Soy, Ralston, IA. Nutrient composition: 85\% DM, 7\% ash, $16 \%$ NDF, $5 \%$ starch, $49 \%$ CP.

${ }^{3}$ Estimated using values from NRC (2001).

possibly a slower absorption rate of $\mathrm{NH}_{3}$ might have led to the observed greater ruminal pool and turnover time of $\mathrm{N}$. Although OG caused a slower ruminal passage rate than $\mathrm{AL}$, a higher $\mathrm{NH}_{3}$ concentration for $\mathrm{AL}$ may reduce the expectation of an increase in efficiency of $\mathrm{N}$ utilization on AL. Treatment effects were not detected for MN flow to the duodenum or for the efficiency of microbial protein synthesis $(\mathrm{g} / \mathrm{g}$ of true ruminally digested OM; Table 4). It is possible that, for microbial synthesis, the positive effects of greater passage rate for $\mathrm{AL}$ were counterbalanced by the positive effects of greater OM digestibility usually observed for OG. However, because a period $\times$ treatment interaction was observed for ruminal OM digestibility, this cannot be confirmed.

Rates of $\mathrm{NH}_{3}$ production, utilization by microbes, absorption from the rumen, and recycling were not measured. However, the higher ruminal concentration of $\mathrm{NH}_{3}$ (apparently greater than microbial demand for $\mathrm{NH}_{3}-\mathrm{N}$ ) and higher ruminal $\mathrm{pH}$ on $\mathrm{AL}$ apparently promoted the absorption of more $\mathrm{N}$ from the rumen as $\mathrm{NH}_{3}$, as indicated by a greater digestibility of $\mathrm{N}$ in the rumen for $\operatorname{AL}(P=0.02)$ and a greater amount of $\mathrm{N}$ disappearing from the rumen $(P=0.02)$ for AL than 
Table 3. Treatment means, $P$-values, and treatment $\times$ preliminary voluntary DMI (pVDMI) interaction coefficients for effects of forage source on $\mathrm{N}$ intake, ruminal digestion, and utilization

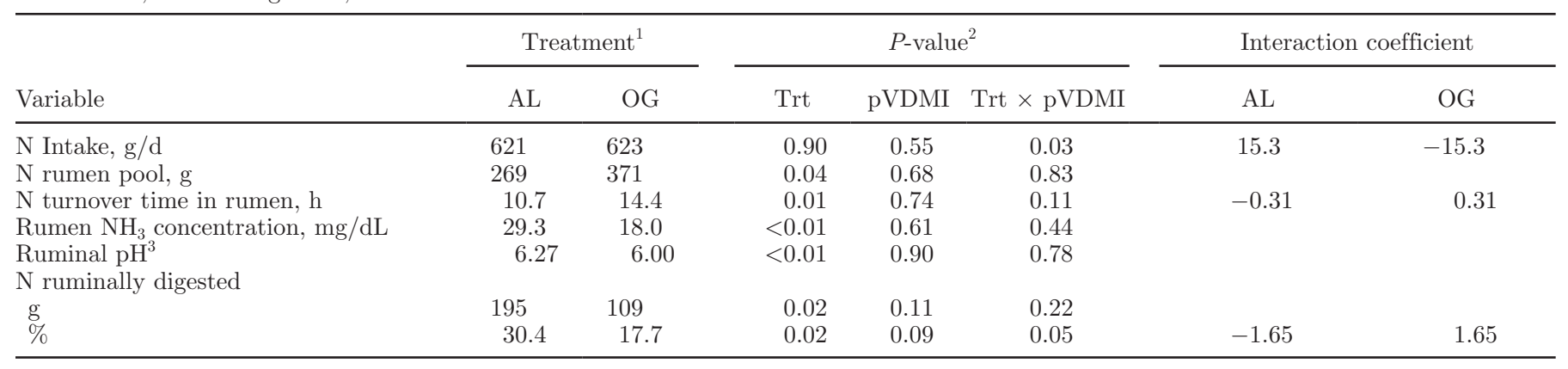

${ }^{1} \mathrm{AL}=$ diet containing alfalfa silage; $\mathrm{OG}=$ diet containing orchardgrass silage.

${ }^{2} \mathrm{Trt}=$ treatment.

${ }^{3}$ Mean of 8 values obtained every $9 \mathrm{~h}$.

for OG (Table 3). Although more $\mathrm{N}$ was absorbed in the rumen for $\mathrm{AL}$, compensatory postruminal digestion of $\mathrm{N}$ occurred for $\mathrm{OG}(P=0.05)$, so that in the whole tract, digestibility of $\mathrm{N}$ and the amount of $\mathrm{N}$ absorbed were similar on both treatments $(P>0.40$; Table 4). Because cows were not ileally cannulated, N disappearance from the small intestine and from the large intestine cannot be differentiated.

\section{N Digestion: Effects of pVDMI}

Nutrient demand, as estimated by individual pVDMI, interacted with treatment to affect $\mathrm{N}$ digestion and uti- lization. Cows in this experiment represent a wide range in $\mathrm{pVDMI}$, and their $\mathrm{N}$ intake responses to treatment depended on pVDMI, as indicated by the significant treatment $\times \mathrm{pVDMI}$ interaction in predicting $\mathrm{N}$ intake $(P=0.03$; Table 3$)$. The coefficient for the interaction term was positive when the treatment was AL $(+15.3)$ and negative when the treatment was OG $(-15.3)$. The interpretation of these coefficients is aided by direct correlations between $\mathrm{N}$ intake and pVDMI for the individual treatments. When the treatment was $\mathrm{AL}, \mathrm{N}$ intake was positively correlated to pVDMI $(P=0.04$; data not shown), but when the treatment was OG, $\mathrm{N}$ intake was not related to $\mathrm{pVDMI}(P>0.50)$. The $\mathrm{N}$ in-

Table 4. Treatment means, $P$-values, and treatment $\times$ preliminary voluntary DMI (pVDMI) interaction coefficients for effects of forage source on $\mathrm{N}$ digestion

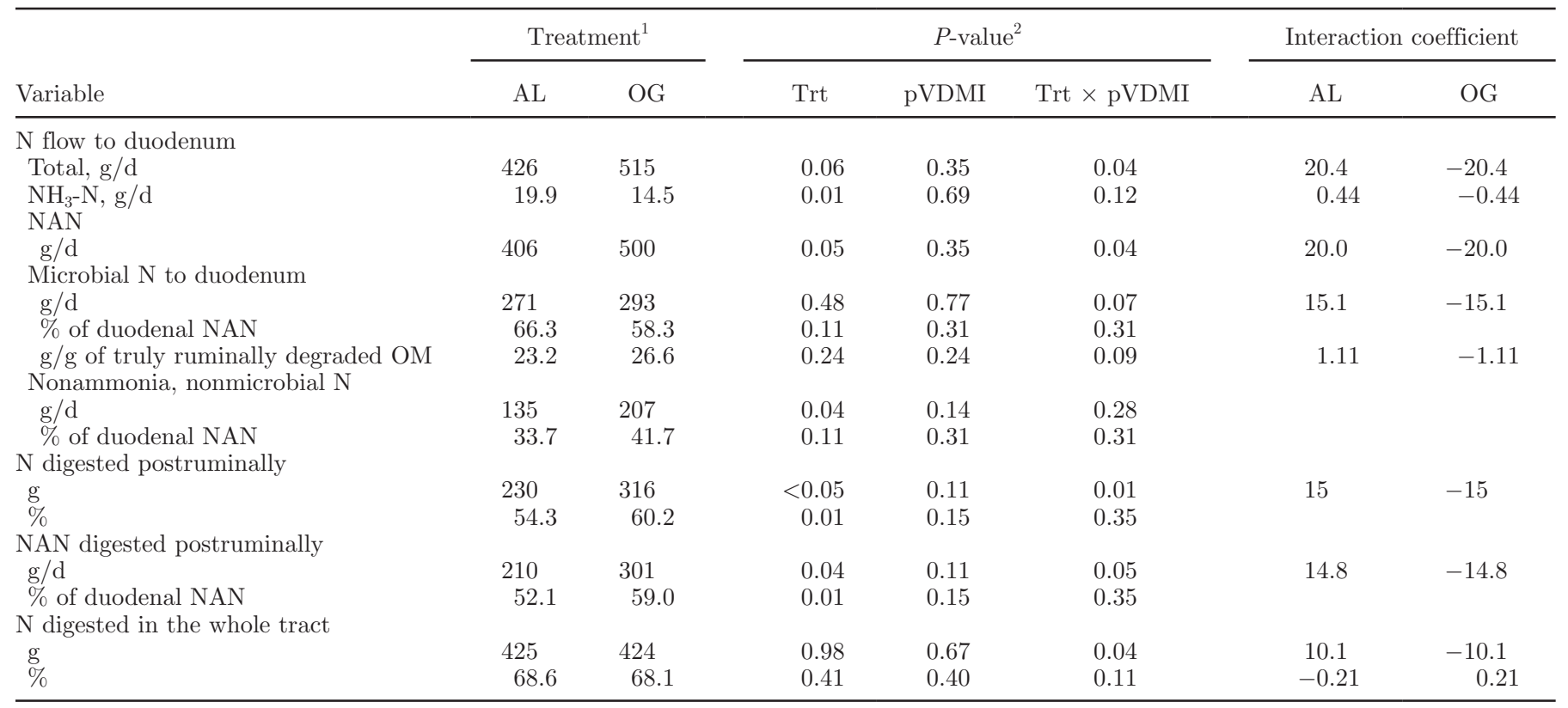

${ }^{1} \mathrm{AL}=$ diet containing alfalfa silage; $\mathrm{OG}=$ diet containing orchardgrass silage.

${ }^{2}$ Trt $=$ treatment. 
take response reflects the interaction observed for DMI response (Voelker Linton and Allen, 2008). Because of greater ruminal fill effects of $\mathrm{OG}, \mathrm{N}$ intake likely was much more limited for OG than for AL among cows with greater pVDMI. As reported elsewhere (Voelker Linton and Allen, 2008), this probably was caused by the inability of passage rate to increase with increasing pVDMI when OG was fed as it did when AL was fed.

Ruminal $\mathrm{N}$ turnover time also was affected by the observed increased passage rate on $\mathrm{AL}$ with increasing pVDMI, probably combined with the likely greater ruminal degradation of nitrogenous compounds on $\mathrm{AL}$ that was discussed earlier. Treatment and pVDMI tended $(P=0.11)$ to interact in affecting $\mathrm{N}$ turnover time (Table 3). The interaction coefficient for $\mathrm{N}$ turnover time was negative when the treatment was $\mathrm{AL}$ $(-0.31)$ and positive when the treatment was OG (0.31; Table 3$)$. Therefore, the increase in passage rate observed for AL with increasing pVDMI apparently permitted shorter turnover time and greater intake of $\mathrm{N}$ for cows with greater pVDMI. For OG, the inability to increase passage rate nearly eliminated the ability of cows with greater pVDMI to reduce turnover time and increase intake of $\mathrm{N}$ and other nutrients to meet nutrient demands.

Furthermore, forage source and pVDMI interacted in their effects on ruminal absorption of $\mathrm{N}$ and on microbial protein production. Ruminal digestibility of $\mathrm{N}$ depended on a treatment $\times$ pVDMI interaction $(P=0.05$; Table $3)$; the interaction coefficient was negative $(-1.65)$ for treatment AL and positive (1.65) for treatment OG. Mechanisms could include changes in the rate or extent of protein degradation, in the rate of absorption of $\mathrm{NH}_{3}$ from the rumen, in the rate or extent of incorporation of $\mathrm{N}$ into microbial protein, or in the rate of passage of N-containing digesta from the rumen. None of these potential mechanisms were measured directly. Ruminal $\mathrm{NH}_{3}$ concentrations did not depend on pVDMI $(P>$ $0.60)$ or on the treatment $\times$ pVDMI interaction $(P>$ 0.40 ), but this does not eliminate the possibility that the rate of either production or absorption of $\mathrm{NH}_{3}$ was affected by pVDMI. As mentioned earlier, lower ruminal $\mathrm{pH}$ can reduce absorption rate of $\mathrm{NH}_{3}$. Treatment and $\mathrm{pVDMI}$ did not interact in predicting daily mean ruminal $\mathrm{pH}(P>0.75$; Table 3$)$. However, treatment responses of ruminal $\mathrm{pH}$ were related to $\mathrm{pVDMI}$ and might have contributed to the interaction observed for ruminal $\mathrm{N}$ digestibility, as follows. When cows were fed $\mathrm{AL}$, daily mean $\mathrm{pH}$ was between 6.1 and 6.6 regardless of pVDMI $(P=0.55)$. When cows were fed $\mathrm{OG}$, mean $\mathrm{pH}$ tended to demonstrate a quadratic relationship to pVDMI, with a maximum at $6.2(P<0.09)$; $\mathrm{pH}$ was particularly lower, around 5.8, among cows with high pVDMI when they were fed OG. This lower ruminal
$\mathrm{pH}$ may have reduced the rate of $\mathrm{NH}_{3}$ absorption from the rumen among cows with high pVDMI when they were fed OG. Therefore, diet effects and pVDMI effects on ruminal $\mathrm{NH}_{3}$ production and absorption may have contributed to the observed responses of ruminal $\mathrm{N}$ digestibility.

As with $\mathrm{N}$ intake, treatment and $\mathrm{pVDMI}$ interacted in affecting flow to the duodenum of total $\mathrm{N}(P=0.04$; Table 4); flow of NAN responded similarly $(P=0.04)$. Flow of MN to the duodenum also depended $(P=0.07)$ on a treatment $\times$ pVDMI interaction (Table 4). This resulted from a numerical increase in MN flow with greater $\mathrm{pVDMI}(P=0.15)$ when cows were fed $\mathrm{AL}$ and a numerical decrease in MN flow with greater pVDMI $(P=0.14)$ when cows were fed OG. Greater duodenal flow of MN with increasing pVDMI for AL compared with OG reflects the greater DM and $\mathrm{N}$ intake, and the greater passage rate, observed with increasing pVDMI for AL compared with OG.

Efficiency of microbial protein production from truly ruminally degraded OM (MN efficiency, MNE) depended on an interaction of treatment and pVDMI $(P=0.09)$; the coefficient for the interaction term was positive for treatment $\mathrm{AL}$ and negative for treatment OG. The negative interaction coefficient for $\mathrm{OG}$ is supported by a significant correlation between pVDMI and MNE when the treatment was OG $(P=0.05)$; no correlation existed when AL was the treatment. When cows were fed OG, MNE decreased linearly with increasing pVDMI. This suggests that, on OG, fermentation and microbial growth were increasingly uncoupled as pVDMI increased, or that lysis was increased by the increasingly negative effect of $\mathrm{OG}$ on passage rate as pVDMI increased. As demonstrated earlier (Voelker Linton and Allen, 2008), passage rate of indigestible NDF tended to be affected negatively by OG compared with $\mathrm{AL}$ as $\mathrm{pVDMI}$ increased. Decreasing passage rate can decrease the efficiency of $\mathrm{N}$ utilization for microbial protein production. With greater passage rate, microbes associated with particulate digesta can escape the rumen more rapidly, reducing microbial protein turnover by reducing the extent of autolysis (Wells and Russell, 1996) and protozoal predation (Wallace and McPherson, 1987). The efficiency with which $\mathrm{N}$ was incorporated into $\mathrm{MN}$, and the turnover of $\mathrm{MN}$ in the rumen, likely contributed to the observed responses of ruminal $\mathrm{N}$ digestion for OG compared with AL.

Just as $\mathrm{N}$ intake and duodenal $\mathrm{N}$ flow were affected by an interaction of treatment and pVDMI, the amount of $\mathrm{N}$ digested postruminally also depended on an interaction of treatment and pVDMI $(P=0.01$; Table 4 ), as did the amount of NAN digested postruminally $(P=0.05)$. The amount of $\mathrm{N}$ digested in the whole tract exhibited a similar interaction $(P=0.04)$, and 
Table 5. Treatment means, $P$-values, and treatment $\times$ preliminary voluntary DMI (pVDMI) interaction coefficients for effects of forage source on $\mathrm{N}$ utilization

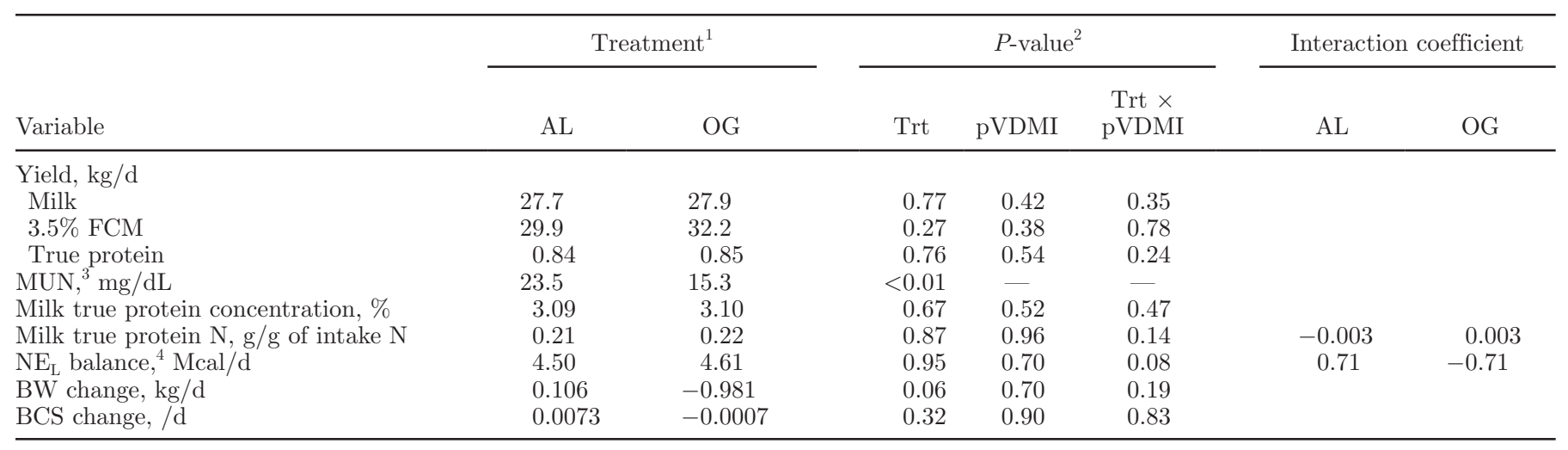

${ }^{1} \mathrm{AL}=$ diet containing alfalfa silage; $\mathrm{OG}=$ diet containing orchardgrass silage.

${ }^{2}$ Trt $=$ treatment.

${ }^{3}$ Measured during only 1 period; treatment effect determined using a $t$-test.

${ }^{4} \mathrm{NE}_{\mathrm{L}}$ balance $=\mathrm{NE}_{\mathrm{L}}$ intake $(\mathrm{Mcal} / \mathrm{d})-$ milk $\mathrm{NE}_{\mathrm{L}}(\mathrm{Mcal} / \mathrm{d})-\mathrm{NE}_{\text {maintenance }}$, according to $\mathrm{NRC}(2001)$.

the interaction coefficients for all 3 measurements were positive for treatment AL and negative for treatment OG (Table 4). Again, the correlations, by treatment, between $\mathrm{pVDMI}$ and response assist in interpreting the interaction. As pVDMI increased, $\mathrm{N}$ digested postruminally decreased for treatment $\mathrm{OG}(P=0.03)$ but did not change for treatment AL $(P>0.80)$. A similar response was observed for NAN digested postruminally. The reduction of $\mathrm{N}$ digested with increasing $\mathrm{pVDMI}$ for $O G$ is likely the result of decreased MN production. Whole-tract $\mathrm{N}$ digestibility also tended $(P=0.11)$ to depend on a treatment $\times$ pVDMI interaction (Table 4) but the signs of the interaction coefficients for $\mathrm{N}$ digestibility were opposite the signs for amount of $\mathrm{N}$ digested (negative for AL and positive for OG; Table 4). These interactions suggest that although AL permitted greater intake and absorption of $\mathrm{N}$ among animals with greater demand, the efficiency of $\mathrm{N}$ utilization did not benefit from the increasingly greater intake and passage rate observed for $\mathrm{AL}$ relative to $\mathrm{OG}$ with increasing pVDMI because $\mathrm{N}$ supply probably was in excess of requirements.

\section{N in Milk Production}

The form in which dietary $\mathrm{N}$ was absorbed might have affected its proportion and form in milk and the efficiency with which it was captured in protein. Mean yield and concentration of true protein in milk did not differ across treatments (Table 5). Although yields of milk and true protein, and milk true protein concentration, were similar between treatments, more $\mathrm{N}$ was secreted in milk in the form of urea for AL than for OG (Table 5). Milk urea $\mathrm{N}$ was measured only during
1 period $(\mathrm{n}=8)$, but MUN was much greater $(P<$ $0.01)$ for cows fed AL $(23.5 \mathrm{mg} / \mathrm{dL})$ than for cows fed OG $(15.3 \mathrm{mg} / \mathrm{dL})$. This is consistent with the greater disappearance of $\mathrm{N}$ from the rumen for $\mathrm{AL}$ compared with OG, probably as $\mathrm{NH}_{3}$, which is used to synthesize urea in the liver. Ruminal $\mathrm{NH}_{3}-\mathrm{N}$ concentration and MUN were highly correlated $\left(P<0.01 ; \mathrm{R}^{2}=0.84\right)$. A dilution of the $\mathrm{N}$ required for maintenance might be expected as pVDMI increases, if milk $\mathrm{N}$ secretion increased with increasing pVDMI. However, neither milk yield nor milk $\mathrm{N}$ yield was related to pVDMI $(P>$ $0.35)$, and neither depended on a treatment $\times$ pVDMI interaction $(P>0.20)$.

Mean efficiency of utilization of $\mathrm{N}$ consumed in the diet for synthesis of true protein in milk (g of milk true protein $\mathrm{N} / \mathrm{g}$ of $\mathrm{N}$ intake) did not differ between treatments (Table 5). However, a weak tendency existed ( $P$ $=0.14)$ for a treatment $\times$ pVDMI interaction, with a negative interaction coefficient for $\mathrm{AL}$ and a positive interaction coefficient for OG (Table 5). This indicates that, with increasing pVDMI, $\mathrm{N}$ tended to be used less efficiently for milk protein production on AL compared with OG. The $\mathrm{N}$ that was not used to produce milk protein likely was secreted in urine and as MUN; urinary $\mathrm{N}$ output was not measured. The reduction in $\mathrm{N}$ utilization for milk true protein likely was caused in part by the positive effect of pVDMI on $\mathrm{N}$ intake observed for AL, combined with the negative effect of pVDMI on whole-tract $\mathrm{N}$ digestibility.

Apparent efficiency of milk protein production from dietary $\mathrm{N}$ also can be increased through mobilization of body tissue protein to meet the demand for milk production. In the interaction of treatment and pVDMI in determining estimated $\mathrm{NE}_{\mathrm{L}}$ balance $(P=0.08$, Table 
$5)$, the positive interaction coefficient for AL and negative coefficient for OG support tissue mobilization as a mechanism for the tendency for increased apparent efficiency of milk true protein synthesis for OG with increasing pVDMI. This is not confirmed through a significant treatment $\times \mathrm{pVDMI}$ interaction for changes in $\mathrm{BW}$ or BCS (Table 5), but changes in BW and BCS are difficult to detect in short experimental periods. In addition to the possible tissue mobilization response, $\mathrm{N}$ intake and $\mathrm{N}$ digestibility responses likely were primary factors in decreasing the efficiency of $\mathrm{N}$ utilization for milk protein production on AL compared with $\mathrm{OG}$ as pVDMI increased. Urinary N output was not measured; it is possible that an increasingly greater amount of digested $\mathrm{N}$ was excreted in urine on $\mathrm{AL}$ than on $\mathrm{OG}$ as pVDMI increased. Although the increasingly greater DMI for AL compared with OG allowed additional $\mathrm{N}$ intake among cows with greater pVDMI, that extra feed $\mathrm{N}$ apparently was digested and utilized less efficiently.

This assertion that utilization of $\mathrm{N}$ may be decreasingly efficient with increasing DMI bears important economic and environmental implications for dairy farms. For all animals in this experiment, energy availability was likely more limiting than protein for milk production. Diets were formulated to ensure that $\mathrm{N}$ and AA availability were not limiting to ruminal fermentation or milk production, and the actual dietary concentration of CP was high (approximately 18.5\% of DM) for both diets. Even with excess dietary total and rumen-degradable $\mathrm{CP}$ in both diets, the effect of diet on whole-tract $\mathrm{N}$ digestibility and efficiency of $\mathrm{N}$ utilization for milk true protein depended on pVDMI. This implies that when practices are implemented to permit greater DMI, dietary $\mathrm{N}$ concentration might need to be reduced to avoid less-efficient digestion and utilization of $\mathrm{N}$.

Furthermore, the effects of pVDMI on $\mathrm{N}$ digestion and utilization reinforce the need to group and feed animals according to some index of nutrient demand. Reducing the variation in energy and protein demand within the group for which a diet is formulated would reduce the extent to which fuels or $\mathrm{N}$ limit ruminal fermentation or milk production in all animals. This would allow diets to be formulated to more accurately meet each individual animal's demands and thus lead to more efficient utilization of $\mathrm{N}$ among all groups of animals on the farm. Increased $\mathrm{N}$ digestion and utilization and more accurate diet formulation will reduce the proportion and amount of $\mathrm{N}$ excreted in urine or feces. It should also reduce the likelihood of overfeeding N. Thus, adjusting feeding practices for the effects of increasing DMI on efficiency of $\mathrm{N}$ utilization can contribute to the reduction of $\mathrm{N}$ waste.

\section{CONCLUSIONS}

As expected, forage family interacted with pVDMI in affecting several measures of $\mathrm{N}$ intake, digestion, and utilization. Intake and duodenal flow of $\mathrm{N}$ increased more for AL than for OG with increasing pVDMI because orchardgrass decreased (relative to alfalfa) the ability of cows to increase DMI consumption (and thus $\mathrm{N}$ consumption) in response to increased appetite. Site of $\mathrm{N}$ digestion and efficiency of the utilization of dietary $\mathrm{N}$ in producing microbial protein and milk true protein also depended on interactions of treatment and pVDMI. A decreasing proportion of the additional $\mathrm{N}$ consumption that was allowed on AL in response to greater nutrient demand was digested and used for increased milk production or body tissue gain. Increasing $\mathrm{N}$ intake at the same rate at which DMI is increased likely will lead to less efficient utilization of dietary $\mathrm{N}$ for production of microbial protein, muscle, or milk true protein. When feeding less-filling diets, such as those containing alfalfa forage, to high-producing cows, reducing dietary $\mathrm{N}$ concentration could increase the efficiency of $\mathrm{N}$ utilization and reduce the extent to which greater DMI leads to greater $\mathrm{N}$ excretion. A better understanding of the different effects of perennial grass and legume forages on $\mathrm{N}$ utilization by cows with different nutrient demands will aid in field management decisions to minimize the turnover and loss of $\mathrm{N}$ on the whole farm.

\section{ACKNOWLEDGMENTS}

We thank D. G. Main, R. A. Longuski, Y. Ying, C. S. Mooney, and B. J. Bradford of the Department of Animal Science at Michigan State University and R. E. Kreft and the staff of the Michigan State University Dairy Cattle Teaching and Research Center for their technical assistance and West Central Soy for the donation of SoyPlus protein supplement. This project was supported by National Research Initiative Competitive Grant no. 2006-35206-16708 from the USDA Cooperative State Research, Education, and Extension Service.

\section{REFERENCES}

Abdoun, K., F. Stumpff, and H. Martens. 2006. Ammonia and urea transport across the rumen epithelium: A review. Anim. Health Res. Rev. 7:43-59.

Broderick, G. A., and J. H. Kang. 1980. Automated simultaneous determination of ammonia and total amino acids in rumen fluid and in vitro media. J. Dairy Sci. 63:64-75.

Hach, C. C., B. K. Bowden, A. B. Lopelove, and S. V. Brayton. 1987. More powerful peroxide Kjeldahl digestion method. J. AOAC 70:783-787.

Isaacson, H. R., F. C. Hinds, M. P. Bryant, and F. N. Owens. 1975. Efficiency of energy utilization by mixed rumen bacteria in continuous culture. J. Dairy Sci. 58:1645-1659. 
Jenness, R. 1985. Biochemical and nutritional aspects of milk and colostrum. Pages 164-197 in Lactation. B. L. Larson, ed. Iowa State University Press, Ames.

Kohn, R. A., and M. S. Allen. 1995. Effect of plant maturity and preservation method on in vitro protein degradation of forages. J. Dairy Sci. 78:1544-1551.

Kwakkel, R. P., J. Van Bruchem, G. Hof, and H. Boer. 1986. The in sacco degradation of crude protein and cell wall constituents in grass, alfalfa and maize silages. Neth. J. Agric. Sci. 34:116-119.

Lammers, B. P., D. R. Buckmaster, and A. J. Heinrichs. 1996. A simple method for the analysis of particle sizes of forage and total mixed rations. J. Dairy Sci. 79:922-928.

Leek, B. F., and R. Harding. 1975. Sensory nervous receptors in the ruminant stomach and the reflex control of reticulo-ruminal motility. Pages $60-76$ in Digestion and Metabolism in the Ruminant. I. W McDonald and A. C. I. Warner, ed. New England Publishing Unit, Armidale, New South Wales, Australia.

NRC. 2001. Nutrient Requirements of Dairy Cattle. 7th rev. ed. National Academy Press, Washington, DC.

Oba, M., and M. S. Allen. 1999. Effects of brown midrib 3 mutation in corn silage on dry matter intake and productivity of high yielding dairy cows. J. Dairy Sci. 82:135-142.

Oba, M., and M. S. Allen. 2003a. Effects of corn grain conservation method on ruminal digestion kinetics for lactating dairy cows at two dietary starch concentrations. J. Dairy Sci. 86:184-194.

Oba, M., and M. S. Allen. 2003b. Effects of diet fermentability on efficiency of microbial nitrogen production in lactating dairy cows. J. Dairy Sci. 86:195-207.

Spandl, E., and O. B. Hesterman. 1997. Forage quality and alfalfa characteristics in binary mixtures of alfalfa and bromegrass or timothy. Crop Sci. 37:1581-1585.
Stouthamer, A. H., and C. Bettenhaussen. 1973. Utilization of energy for growth and maintenance in continuous and batch cultures of microorganisms. Biochim. Biophys. Acta 301:53-70.

Voelker, J. A., and M. S. Allen. 2003. Pelleted beet pulp substituted for high-moisture corn: 3. Efffects on rumen fermentation, $\mathrm{pH}$, and microbial protein efficiency in lactating dairy cows. J. Dairy Sci. $86: 3562-3570$

Voelker, J. A., G. M. Burato, and M. S. Allen. 2002. Effects of pretrial milk yield on responses of feed intake, digestion, and production to dietary forage concentration. J. Dairy Sci. 85:2650-2661.

Voelker Linton, J. A., and M. S. Allen. 2007. Nutrient demand affects ruminal digestion responses to a change in dietary forage concentration. J. Dairy Sci. 90:4770-4779.

Voelker Linton, J. A., and M. S. Allen. 2008. Nutrient demand interacts with forage family to affect intake and digestion responses in dairy cows. J. Dairy Sci. 91:2694-2701.

Waghorn, G. C., I. D. Shelton, and V. J. Thomas. 1989. Particle breakdown and rumen digestion of fresh ryegrass (Lolium perenne L.) and lucerne (Medicago sativa L.) fed to cows during a restricted feeding period. Br. J. Nutr. 61:409-423.

Wallace, R. J., and C. A. McPherson. 1987. Factors affecting the rate of breakdown of bacterial protein in rumen fluid. Br. J. Nutr. 58:313-323.

Wells, J. E., and J. B. Russell. 1996. Why do so many ruminal bacteria die and lyse so quickly? J. Dairy Sci. 79:1487-1495.

Wilson, J. R., and R. D. Hatfield. 1997. Structural and chemical changes of cell wall types during stem development: Consequences for fibre degradation by rumen microflora. Aust. J. Agric. Res. $48: 165-180$.

Zinn, R. A., and F. N. Owens. 1986. A rapid procedure for purine measurement and its use for estimating net ruminal protein synthesis. Can. J. Anim. Sci. 66:157-166. 